\title{
A Study on Project Planning Using the Deterministic and Probabilistic Models by Network Scheduling Techniques
}

\author{
Rama.S $S^{1}$, Sathya $A^{2}$, Shasikala $A^{3}$, and Cilfa Irene ${ }^{4}$
}

\begin{abstract}
:
Project planning is the important task in many areas like construction, resource allocation and many. A sequence of activities has to be performed to complete one task. Each activity has its unique processing time and all together to identify the critical activities which affect the completion of the project. In this paper the probabilistic and deterministic models to determine the project completion time and also the critical activities are considered. A case study on building construction project has been performed to demonstrate the application of the above said models. The two project scheduling namely PERT and CPM are used to determine numerically the different types of floating times of each activity and hence determined the critical path which plays an important role in the project completion time. Also a linear programing model has been developed to reduce the project completion time which optimize the resource allocation. To apply these techniques numerically the primary data from a housing project company in a metropolitan city has been taken, the network diagram of the activities involved in the building construction project has been drawn and the results are tabulated.
\end{abstract}

Keywords: Project scheduling, Probabilistic model, Deterministic model, CPM, PERT, Linear programming.

\section{INTRODUCTION}

A project consists of various activities which are mutually relative. There is a certain order to implement each activity before completing it. Some of the activities are independent to other activities and can be started right away while some other activities are dependent on completion of preceding activity or done simultaneously. Planning and scheduling are important aspects in project management. Network scheduling is an effective technique widely used in planning and scheduling of projects especially in construction projects. Nowadays housing construction project are common. Building a house within reasonable budget and in short time can be difficult without any planning. Good scheduling can effectively help in construction project management. Network scheduling will help construction companies (engineers) to finish their task in time and within reasonable budget. In network scheduling, PERT (Project Evaluation and Review Technique) and CPM (Critical Path Method) are valuable techniques used in planning, scheduling and controlling of construction projects. These techniques are used to calculate the earliest start, earliest finish, latest start, latest finish, and different types of float for each activity, hence thereafter to calculate the critical activities and critical paths. These techniques are used to provide analytical means for scheduling the activities by defining the project activities, their precedence relation-ships and their specific time requirements. The main advantage of Critical Path Analysis is to find the minimum duration of time required to complete the project (Adebowale et al. 2011). With the help of PERT and CPM it is possible to follow the actual progress of the project and evaluate the proposed alternatives with respect to cost and time. PERT method allows the calculation of the average time needed for completion of a project, identification of critical activities and estimations of probabilities of achieving the planned deadlines. (Gurau et al. 2012)

Dhirendra Rao (1978) explained the application of project scheduling in two main services of knowledge information center namely abstracting services and referencing services and concluded that balancing and completion of project on time would be optimized using these techniques. Gerald (1986) developed a mathematical model which optimizes the monitoring behavior of transcutaneous $\mathrm{pCo} 2$ which analyze the changes happening in the premature infants having respiratory diseases. Koteswara Rao et. al. (2008) developed a prototype tool to select an optimal policy obtained from fuzzy PERT network whereas the main constraints are considered viz., cost, manpower and unlisted points to crash the time.Fahimifard et al. (2009) applied project scheduling techniques in Agricultural Research Center of University of Zabol and reduced the cost and time estimation. Adebowaleet al. (2011) has estimated the cost and time duration to complete the project of a civil engineering companyALMEGA, Nig. Ltd. Adegoke (2011) used time scheduling technique to solve parking space issue 
faced by various organization. Elambrouk (2011) used project scheduling technique to identify the critical activities and Linear Programming technique to crash the activities so as to optimize the cost and project completion time. Rotarescu (2011) applied the project scheduling management technique in human resource organization and produced a mathematical model to optimize the performance of the workers. Gurau et.al (2012) explained the uses of PERT and CPM to expand the furniture manufacturing company's favorable circumstances for sale on the internet and in examination of critical path. This paper concludes PERT/CPM of Win QSB helps us to choose the appropriate economic approach and a new view of facilitating decision for an enterprise. Rautela et al.(2012) applied project scheduling technique in large scale industries like shoe manufacturing industry and completion time has been calculated without delaying any activities.

Elmabrouk (2012) used linear programming and CPM to develop the model which helps a project manager to determine the crash cost and crash time in construction. Paramveer Singh et al. (2013) used the project scheduling techniques in designing and replicating of the formation of human resources and proved that the project can be complete before the normal scheduled time which also would increase confidence and fulfillment among the workers. Rashmi Agarwal et al. (2013) explained planning and control techniques of operations research. Vikash Agarwal et al. (2013) had made a comparative study on time-cost trade off problems (TCTP) using CPM and PERT. Peng Wang (2013) derived Ant colony optimization algorithm (ACO) and Genetic Algorithm (GA) using PERT network diagram. Tamrakar (2013) implemented the critical path method in a project based company for analyzing the completion of an arbitrary project. Chatwal (2014) defined a simulated project scheduling technique for wide range of simplex problem which have large area of application. Aditi et al. (2014) modeled the construction project management by optimizing the time and cost of the project using critical path method. Shailla (2014) adapted a comparative study in hardware and software product research and development using CPM. Rajguru et al. (2016) proved mathematically that cost and time are the main aspects to be considered in the planning of every project by adopting the project scheduling techniques.

The main objective of this paper to minimize the schedule time and the cost for completion of the project with adequate resources. In this paper, the project scheduling techniques CPM and PERT are used efficiently to optimize the cost and the time required to construct a house in a metropolitan city. CPM is used to produce a graphical representation of the project and hence find the critical activities which have to be focused more on completion of project in time. These critical activities form the critical path. PERT is used to calculate the project completion time, by considering the probabilistic model of the construction project. To reduce the duration of any project, a method called project crashing is used. It is done by reducing the duration of each critical activity.

\section{CONSTRUCTION OF NETWORK DIAGRAM}

The sequences of activities involved in the projects are listed out to draw the network diagram. To draw the network diagram of the project the precedence relationship of the activities are to be determined. Network diagram is the graphical representation of activities that have to be attempted and completed to execute the project. Arrows and circles are the two symbols used to draw the network. Arrows are used to represent the activities. Each activity is preceded and succeeded by an event, represented by numbered circles and are referred as tail event and head event respectively. Preceding activity is an activity which must be finished before starting the next activity. Succeeding activity is an activity which must begin only after the completion of preceding activity. Any two events are joined only by one activity. If any two activities have same tail event or head event then a dummy activity would be introduced by dotted arrow line. Clearly it is an imaginary activity and is not a part of the project activities. In the network diagram the events are numbered from left to right by using Fulkerson's rule.

For numerical study a house construction project in a metropolitan city has been considered and the corresponding data produced in Table 1

Table.1 Data for construction of a house in metropolitan city

\begin{tabular}{|l|l|l|l|l|}
\hline Activity code & $\begin{array}{l}\text { Name of the } \\
\text { Activity }\end{array}$ & Normal cost & $\begin{array}{l}\text { Immediate } \\
\text { predecessor }\end{array}$ & $\begin{array}{l}\text { Estimated } \\
\text { duration }\end{array}$ \\
\hline A & Site clearing & 3000 & - & 1 \\
\hline B & Excavation cement & 10000 & A & 2 \\
\hline C & $\begin{array}{l}\text { Pcc-Plain } \\
\text { concrete for bed1 }\end{array}$ & B & 1 \\
\hline D & Column footing and & 102600 & C & 5 \\
\hline
\end{tabular}




\begin{tabular}{|c|c|c|c|c|}
\hline & $\begin{array}{l}\text { column raising up to } \\
\text { plinth level }\end{array}$ & & & \\
\hline $\mathrm{E}$ & Foundation & 60000 & $\mathrm{D}$ & 3 \\
\hline $\mathrm{F}$ & Basement & 39900 & $\mathrm{E}$ & 2 \\
\hline $\mathrm{G}$ & Plinth Beam-RCC & 65900 & $\mathrm{~F}$ & 3 \\
\hline $\mathrm{H}$ & $\begin{array}{l}\text { Column raising up } \\
\text { to lintel level }\end{array}$ & 45000 & $\mathrm{G}$ & 6 \\
\hline I & $\begin{array}{ll}\begin{array}{l}\text { Super } \\
\text { (wall) }\end{array} & \text { structure } \\
\end{array}$ & 90450 & $\mathrm{H}$ & 15 \\
\hline $\mathrm{J}$ & $\begin{array}{l}\text { Electrical pipes and } \\
\text { box fitting }\end{array}$ & 150000 & I & 3 \\
\hline $\mathrm{K}$ & Roof-RCC & 131600 & $\mathrm{~J}$ & 7 \\
\hline $\mathrm{L}$ & Lintel and sunshade & 20000 & $\mathrm{~K}$ & 4 \\
\hline $\mathrm{M}$ & $\begin{array}{l}\text { Door and window } \\
\text { frame fixing }\end{array}$ & 50000 & $\mathrm{~L}$ & 3 \\
\hline $\mathrm{N}$ & $\begin{array}{ll}\begin{array}{l}\text { Plumbing } \\
\text { sanitary pipes }\end{array} & \text { and } \\
\end{array}$ & 50000 & $\mathrm{M}$ & 3 \\
\hline $\mathrm{O}$ & Plastering & 108200 & $\mathrm{~N}$ & 5 \\
\hline $\mathrm{P}$ & Hand rails fixing & 80000 & $\mathrm{~N}, \mathrm{O}$ & 6 \\
\hline $\mathrm{Q}$ & Flooring & 66000 & $\mathrm{I}, \mathrm{J}, \mathrm{P}$ & 10 \\
\hline $\mathrm{R}$ & Dadoing & 28000 & Q & 3 \\
\hline $\mathrm{S}$ & $\begin{array}{l}\text { Door and window } \\
\text { shutter fixing }\end{array}$ & 88778 & $\mathrm{~N}, \mathrm{M}$ & 3 \\
\hline $\mathrm{T}$ & Painting & 95534 & $\mathrm{~S}$ & 10 \\
\hline $\mathrm{U}$ & Interior fixtures & 85000 & Q & 10 \\
\hline $\mathrm{V}$ & $\begin{array}{l}\text { Electrification with } \\
\text { all fitting }\end{array}$ & 50000 & $\mathrm{~N}$ & 5 \\
\hline $\mathrm{W}$ & Cladding & 30000 & $\mathrm{O}$ & 5 \\
\hline $\mathrm{X}$ & Landscaping & 20000 & $\mathrm{U}$ & 5 \\
\hline
\end{tabular}

The precedence relationship for the activity is

$\mathrm{A}<\mathrm{B} ; \mathrm{B}<\mathrm{C} ; \mathrm{C}<\mathrm{D} ; \mathrm{D}<\mathrm{E} ; \mathrm{E}<\mathrm{F} ; \mathrm{F}<\mathrm{G} ; \mathrm{G}<\mathrm{H}$;

$\mathrm{H}<\mathrm{I} ; \mathrm{I}<\mathrm{J} ; \mathrm{J}<\mathrm{K} ; \mathrm{K}<\mathrm{L} ; \mathrm{L}<\mathrm{M} ; \mathrm{M}<\mathrm{N} ; \mathrm{N}<\mathrm{O}$;

$\mathrm{O}<\mathrm{P} ; \mathrm{I}, \mathrm{J}, \mathrm{P}<\mathrm{Q} ; \mathrm{Q}<\mathrm{R} ; \mathrm{N}, \mathrm{M}<\mathrm{S} ; \mathrm{S}<\mathrm{T} ; \mathrm{Q}<\mathrm{U}$;

$\mathrm{N}<\mathrm{V} ; \mathrm{O}<\mathrm{W} ; \mathrm{U}<\mathrm{X}$

(1)

Using the precedence relationship given in equation (1) the network diagram of the project has been prepared and given in Figure 1.

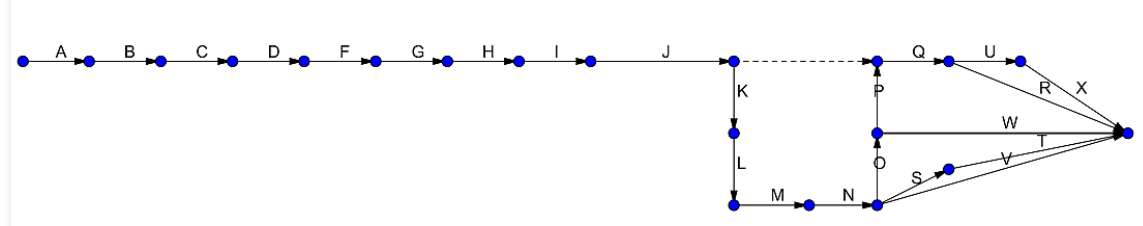

Figure 1.The network diagram of the construction project in a metropolitan city.

\section{ESTIMATION OF ACTIVITY TIMES}

\subsection{Deterministic model:}

CPM is a deterministic model whose results have some certainty. By using this deterministic model the different time estimates and floats for each activity have been determined by using to computation techniques namely forward pass computation and backward pass computation.

Using forward pass computation

$$
\mathrm{ES}(1)=\mathrm{EC}(1)=0
$$

$$
\begin{aligned}
& E S(\mathrm{j})=\underset{i \in P(j), i^{*}}{\operatorname{Max}} E C(i) \\
& E C(\mathrm{j})=E S(\mathrm{j})+\mathrm{t}_{\mathrm{i} * \mathrm{j}}, \text { for } \mathrm{i}=2: \mathrm{n}
\end{aligned}
$$

Using backward pass computation

$$
\begin{aligned}
& \mathrm{LC}(\mathrm{n})=\mathrm{EC}(\mathrm{n}) \\
& \mathrm{LC}(\mathrm{i})=\operatorname{Min}_{j \in S(i), j^{*}} L C(i)
\end{aligned}
$$

$\mathrm{LS}(\mathrm{i})=\mathrm{LC}(\mathrm{i})-\mathrm{t}_{\mathrm{ij}} \mathrm{j}^{*}$, for $\mathrm{i}=\mathrm{n}-1:-1: 1$

The total float is

$$
\mathrm{T} \mathrm{F}=\mathrm{LS}-\mathrm{ES}=\mathrm{LC}-\mathrm{EC}
$$

The total time completion of the project

$$
\mathrm{T}_{\mathrm{p}}=\mathrm{LC}(\mathrm{n})
$$


Using the data given in table. 1 the different time estimates and floats have been calculated and are tabulated in table 2. The symbols used are explained in Appendix A.

Table 2. Time estimates and total float using CPM method

\begin{tabular}{|l|l|l|l|l|l|l|}
\hline $\begin{array}{l}\text { Activity } \\
\text { code }\end{array}$ & Time & Earliest start & $\begin{array}{l}\text { Earliest } \\
\text { Finish }\end{array}$ & Latest Start & $\begin{array}{l}\text { Latest } \\
\text { Finish }\end{array}$ & Total Float \\
\hline A & 1 & 0 & 1 & 0 & 1 & 0 \\
\hline B & 2 & 1 & 3 & 1 & 3 & 0 \\
\hline C & 1 & 3 & 4 & 3 & 4 & 0 \\
\hline D & 5 & 4 & 9 & 4 & 9 & 0 \\
\hline E & 3 & 9 & 12 & 9 & 12 & 0 \\
\hline F & 2 & 12 & 14 & 12 & 14 & 0 \\
\hline G & 3 & 14 & 17 & 14 & 17 & 0 \\
\hline H & 6 & 17 & 23 & 17 & 23 & 0 \\
\hline I & 15 & 23 & 38 & 23 & 38 & 0 \\
\hline J & 3 & 38 & 41 & 38 & 41 & 0 \\
\hline K & 7 & 41 & 48 & 41 & 48 & 0 \\
\hline L & 4 & 48 & 52 & 48 & 52 & 0 \\
\hline M & 3 & 52 & 55 & 52 & 55 & 0 \\
\hline N & 3 & 55 & 58 & 55 & 58 & 0 \\
\hline O & 5 & 58 & 63 & 58 & 63 & 0 \\
\hline P & 6 & 63 & 69 & 63 & 69 & 0 \\
\hline Q & 10 & 69 & 79 & 69 & 79 & 0 \\
\hline R & 3 & 79 & 82 & 91 & 94 & 12 \\
\hline S & 3 & 58 & 61 & 81 & 84 & 23 \\
\hline T & 10 & 61 & 71 & 84 & 94 & 23 \\
\hline U & 10 & 79 & 89 & 79 & 89 & 0 \\
\hline V & 5 & 58 & 63 & 89 & 94 & 31 \\
\hline W & 5 & 63 & 68 & 89 & 94 & 26 \\
\hline X & 5 & 89 & 94 & 89 & 94 & 0 \\
\hline & & & & & & \\
\hline
\end{tabular}

\subsection{Probabilistic model:}

The three time duration of each activity namely optimistic, most likely and pessimistic time are considered. The expected time and variance for each activity are given

$$
\mathrm{t}_{\mathrm{e}}=\left(\mathrm{t}_{0}+4 \mathrm{t}_{\mathrm{m}}+\mathrm{t}_{\mathrm{p}}\right) / 6
$$

$$
\text { Variance }=\left(\left(\mathrm{t}_{\mathrm{p}}-\mathrm{t}_{0}\right) / 6\right)^{2}
$$

Sum of variance of all critical activities will give variance of total time of the project. Table 3 gives the probabilistic data for the construction project and the estimated variance and average time.

Table.3 Estimated time for probabilistic model by PERT

\begin{tabular}{|l|l|l|l|l|l|l|}
\hline $\begin{array}{l}\text { Activity } \\
\text { code }\end{array}$ & $\begin{array}{l}\text { Immediate } \\
\text { predecessor }\end{array}$ & $\mathrm{t}_{0}$ & $\mathrm{t}_{\mathrm{m}}$ & $\mathrm{t}_{\mathrm{p}}$ & $\mathrm{t}_{\mathrm{e}}$ & Variance \\
\hline $\mathrm{A}$ & - & 1 & 1 & 1 & 1 & 0 \\
\hline $\mathrm{B}$ & $\mathrm{A}$ & 1 & 2 & 3 & 2 & $1 / 9$ \\
\hline $\mathrm{C}$ & $\mathrm{B}$ & 1 & 0.5 & 3 & 1 & $1 / 9$ \\
\hline $\mathrm{D}$ & $\mathrm{C}$ & 3 & 5 & 7 & 5 & $4 / 9$ \\
\hline $\mathrm{E}$ & $\mathrm{D}$ & 2 & 3 & 4 & 3 & $1 / 9$ \\
\hline $\mathrm{F}$ & $\mathrm{E}$ & 1 & 2 & 3 & 2 & $1 / 9$ \\
\hline $\mathrm{G}$ & $\mathrm{F}$ & 2 & 3 & 4 & 3 & $1 / 9$ \\
\hline $\mathrm{H}$ & $\mathrm{G}$ & 1 & 6 & 11 & 6 & $25 / 9$ \\
\hline $\mathrm{I}$ & $\mathrm{H}$ & 6 & 16 & 20 & 15 & $49 / 9$ \\
\hline $\mathrm{J}$ & $\mathrm{I}$ & 1 & 3 & 5 & 3 & $4 / 9$ \\
\hline $\mathrm{K}$ & $\mathrm{J}$ & 4 & 7 & 10 & 7 & 1 \\
\hline $\mathrm{L}$ & $\mathrm{K}$ & 2 & 4 & 6 & 4 & $4 / 9$ \\
\hline $\mathrm{M}$ & $\mathrm{L}$ & 1 & 3 & 5 & 3 & $4 / 9$ \\
\hline $\mathrm{N}$ & $\mathrm{M}$ & 2 & 3 & 4 & 3 & $1 / 9$ \\
\hline $\mathrm{O}$ & $\mathrm{N}$ & 3 & 5 & 7 & 5 & $4 / 9$ \\
\hline $\mathrm{P}$ & $\mathrm{N}, \mathrm{O}$ & 4 & 5.5 & 10 & 6 & 1 \\
\hline
\end{tabular}




\begin{tabular}{|l|l|l|l|l|l|l|}
\hline $\mathrm{Q}$ & $\mathrm{I}, \mathrm{J}, \mathrm{P}$ & 5 & 10 & 15 & 10 & $25 / 9$ \\
\hline $\mathrm{R}$ & $\mathrm{Q}$ & 1 & 3 & 5 & 3 & $4 / 9$ \\
\hline $\mathrm{S}$ & $\mathrm{N}, \mathrm{M}$ & 1 & 3 & 5 & 3 & $4 / 9$ \\
\hline $\mathrm{T}$ & $\mathrm{S}$ & 8 & 10 & 12 & 3 & $4 / 9$ \\
\hline $\mathrm{U}$ & $\mathrm{Q}$ & 7 & 10 & 13 & 10 & 1 \\
\hline $\mathrm{V}$ & $\mathrm{N}$ & 2 & 5 & 8 & 5 & 1 \\
\hline $\mathrm{W}$ & $\mathrm{O}$ & 3 & 5 & 7 & 5 & $4 / 9$ \\
\hline $\mathrm{X}$ & $\mathrm{U}$ & 4 & 5 & 6 & 5 & $1 / 9$ \\
\hline
\end{tabular}

\section{DETERMINATION OF CRITICAL ACTIVITIES AND CRITICAL PATH}

Any activity whose total float is zero has been considered as critical activity. The path connecting the critical activities forms the critical path. These critical activities delay would affect the project on time completion. The activities which are having positive value as total float would not affect the project complete if the activities are delayed. For the construction project from Table 2 the critical activities and critical path are determined

Critical Activities: A B C D E F G H I J K L M N O P Q U and X

Critical Path:-1-2 2-3 3-4 4-5 5-6 6-7 7-8 8-9 9-10 1011 11-12 12-13 13-1414-15 $15-16 \quad 16-18 \quad 18-19$ 19$2020-21$.
The total estimation time of the project has been calculated as 94 days. The probability to delay the project for 4 more days has been estimated as $83 \%$.

\section{TIME-COST TRADE-OFF}

Even though CPM/PERT minimizes the project duration and the cost, sometimes the project managers are compelled to complete the project before the deadline. This has been done by increasing the labor and material cost. Crashing is a method used to decrease the project duration by reducing the duration of critical activities from it's the normal duration. Cost Slope for each activity has been calculated as

Cost slope $=($ Crash cost - Normal Cost $) /($ Normal time - Crash time)

Crash time is the minimum duration in which the particular activity should be finished. Table 4 gives the crash slope for each activity considered in the project.

Table 4 Crash slope for each activity

\begin{tabular}{|l|l|l|l|l|l|l|l|}
\hline $\begin{array}{l}\text { Activity } \\
\text { code }\end{array}$ & $\begin{array}{l}\text { Normal } \\
\text { Time }\end{array}$ & $\begin{array}{l}\text { Normal } \\
\text { Cost }\end{array}$ & $\begin{array}{l}\text { Crash } \\
\text { Time }\end{array}$ & $\begin{array}{l}\text { Crash } \\
\text { cost }\end{array}$ & $\Delta \mathrm{c}$ & $\Delta \mathrm{t}$ & $\mathrm{r}=\Delta \mathrm{c} / \Delta \mathrm{t}$ \\
\hline A & 1 & 3000 & $1 / 2$ & 4050 & 1050 & $1 / 2$ & 2100 \\
\hline B & 2 & 10000 & 1 & 15000 & 5000 & 1 & 5000 \\
\hline C & 1 & 5740 & $1 / 2$ & 8610 & 2870 & $1 / 2$ & 5740 \\
\hline D & 5 & 102600 & 3 & 138510 & 35910 & 2 & 17955 \\
\hline E & 3 & 60000 & 2 & 72000 & 12000 & 1 & 12000 \\
\hline F & 2 & 39900 & 1 & 53865 & 13965 & 1 & 13965 \\
\hline G & 3 & 65900 & 2 & 82375 & 16475 & 1 & 16475 \\
\hline H & 6 & 45000 & 5 & 51750 & 6750 & 1 & 6750 \\
\hline I & 15 & 90450 & 13 & 113060 & 22610 & 2 & 11305 \\
\hline J & 3 & 150000 & 2 & 202500 & 52500 & 1 & 52500 \\
\hline K & 7 & 131600 & 5 & 177660 & 46060 & 2 & 23030 \\
\hline L & 4 & 20000 & 2 & 31000 & 11000 & 2 & 5500 \\
\hline M & 3 & 50000 & 2 & 62500 & 12500 & 1 & 12500 \\
\hline N & 3 & 50000 & 2 & 65000 & 15000 & 1 & 15000 \\
\hline O & 5 & 108200 & 3 & 146070 & 37870 & 2 & 18935 \\
\hline P & 6 & 80000 & 5 & 100000 & 20000 & 1 & 20000 \\
\hline Q & 10 & 66000 & 8 & 89100 & 23100 & 2 & 1550 \\
\hline R & 3 & 28000 & 2 & 35000 & 7000 & 1 & 7000 \\
\hline S & 3 & 88778 & 2 & 119848 & 31070 & 1 & 31070 \\
\hline T & 10 & 95534 & 9 & 109864 & 14330 & 1 & 14330 \\
\hline U & 10 & 85000 & 8 & 106250 & 21250 & 2 & 10625 \\
\hline V & 5 & 50000 & 3 & 70000 & 20000 & 2 & 10000 \\
\hline W & 5 & 30000 & 4 & 40500 & 10500 & 1 & 10500 \\
\hline X & 5 & 20000 & 3 & 25000 & 5000 & 2 & 2500 \\
\hline & & & & & & & \\
\hline
\end{tabular}

To minimize this crash cost a linear programming model has been formulated. Let $\mathrm{Z}$ as the overall cost for crashing the activities and $\mathrm{Xi}$, $(\mathrm{i}=\mathrm{A}, \mathrm{B}, \mathrm{C} \ldots \mathrm{X})$ are the decision variables, denote 
the activity duration. Yi-start time of $\mathrm{i}^{\text {th }}$ activity (i=B,C,D,E,F,G,I,J,K,L,M,N,O,P,Q,R,S,T,U,V,W,

$\mathrm{X})$. The problem has been formulated as

\section{Objective function:}

Min $\mathrm{z}=2100 \mathrm{X}_{\mathrm{A}}+5000 \mathrm{X}_{\mathrm{B}}+5740 \mathrm{X}_{\mathrm{C}}+17955 \mathrm{X}_{\mathrm{D}}$ $+12000 \mathrm{X}_{\mathrm{E}}+13965 \mathrm{X}_{\mathrm{F}}+16475 \mathrm{X}_{\mathrm{G}}+6750 \mathrm{X}_{\mathrm{H}}+$ $11305 X_{I}+52500 X_{J}+23030 X_{K}+5500 X_{L}+$ $12500 X_{M}+15000 X_{N}+18935 X_{O}+20000 X_{P}+$ $11550 \mathrm{X}_{\mathrm{Q}}+7000 \mathrm{X}_{\mathrm{R}}+31070 \mathrm{X}_{\mathrm{S}}+14330 \mathrm{X}_{\mathrm{T}}+$ $10625 X_{U}+10000 X_{V}+10500 X_{W}+2000 X_{X}$

Slope time constraints:

$\mathrm{X}_{\mathrm{A}} \leq 0.5, \quad \mathrm{X}_{\mathrm{B}} \leq 1, \quad \mathrm{X}_{\mathrm{C}} \leq 0.5, \quad \mathrm{X}_{\mathrm{D}} \leq 2, \quad \mathrm{X}_{\mathrm{E}} \leq 1$, $X_{F} \leq 1, X_{G} \leq 1, X_{H} \leq 1, X_{I} \leq 2, X_{J} \leq 1, X_{K} \leq 2$, $X_{L} \leq 2, X_{M} \leq 1, X_{N} \leq 1, X_{O} \leq 2, X_{P} \leq 1, X_{Q} \leq 2$, $X_{R} \leq 1, X_{S} \leq 1, X_{T} \leq 1, X_{U} \leq 2, X_{V} \leq 2, X_{W} \leq 1$, $\mathrm{X}_{\mathrm{X}} \leq 2$

Start time constraints:

$\mathrm{Y}_{\mathrm{B}}+\mathrm{X}_{\mathrm{A}} \geq 1, \mathrm{Y}_{\mathrm{C}^{-}} \mathrm{Y}_{\mathrm{B}}+\mathrm{X}_{\mathrm{B}} \geq 2, \mathrm{Y}_{\mathrm{D}^{-}} \mathrm{Y}_{\mathrm{C}}+\mathrm{X}_{\mathrm{C}} \geq 1$,

$Y_{E}-Y_{D}+X_{D} \geq 5, Y_{F}-Y_{E}+X_{E} \geq 3, Y_{G}-Y_{F}+X_{F} \geq 2$,

$\mathrm{Y}_{\mathrm{H}^{-}} \mathrm{Y}_{\mathrm{G}}+\mathrm{X}_{\mathrm{G}} \geq 6, \mathrm{Y}_{\mathrm{I}^{-}} \mathrm{Y}_{\mathrm{H}}+\mathrm{X}_{\mathrm{H}} \geq 6, \mathrm{Y}_{\mathrm{J}^{-}} \mathrm{Y}_{\mathrm{I}}+\mathrm{X}_{\mathrm{I}} \geq 15$,

$\mathrm{Y}_{\mathrm{K}}-\mathrm{Y}_{\mathrm{J}}+\mathrm{X}_{\mathrm{J}} \geq 3, \mathrm{Y}_{\mathrm{L}}-\mathrm{Y}_{\mathrm{K}}+\mathrm{X}_{\mathrm{K}} \geq 7, \mathrm{Y}_{\mathrm{M}}-\mathrm{Y}_{\mathrm{L}}+\mathrm{X}_{\mathrm{L}} \geq 4$

$\mathrm{Y}_{\mathrm{N}}-\mathrm{Y}_{\mathrm{M}}+\mathrm{X}_{\mathrm{M}} \geq 3, \mathrm{Y}_{\mathrm{O}}-\mathrm{Y}_{\mathrm{N}}+\mathrm{X}_{\mathrm{N}} \geq 3, \mathrm{Y}_{\mathrm{P}^{-}} \mathrm{Y}_{\mathrm{O}}+\mathrm{X}_{\mathrm{O}} \geq 5$,

$\mathrm{Y}_{\mathrm{P}}-\mathrm{Y}_{\mathrm{N}}+\mathrm{X}_{\mathrm{N}} \geq 3, \mathrm{Y}_{\mathrm{Q}^{-}} \mathrm{Y}_{\mathrm{I}}+\mathrm{X}_{\mathrm{I}} \geq 15, \mathrm{Y}_{\mathrm{Q}} \mathrm{Y}_{\mathrm{J}}+\mathrm{X}_{\mathrm{J}} \geq 3$,

$\mathrm{Y}_{\mathrm{Q}^{-}} \mathrm{Y}_{\mathrm{P}}+\mathrm{X}_{\mathrm{P}} \geq 6, \mathrm{Y}_{\mathrm{R}}-\mathrm{Y}_{\mathrm{Q}}+\mathrm{X}_{\mathrm{Q}} \geq 10, \mathrm{Y}_{\mathrm{S}^{-}} \mathrm{Y}_{\mathrm{N}}+\mathrm{X}_{\mathrm{N}} \geq 3$,

$\mathrm{Y}_{\mathrm{S}}-\mathrm{Y}_{\mathrm{M}}+\mathrm{X}_{\mathrm{M}} \geq 3, \mathrm{Y}_{\mathrm{T}}-\mathrm{Y}_{\mathrm{S}}+\mathrm{X}_{\mathrm{S}} \geq 3, \mathrm{Y}_{\mathrm{U}}-\mathrm{Y}_{\mathrm{Q}}+\mathrm{X}_{\mathrm{Q}} \geq 10$,

$\mathrm{Y}_{\mathrm{V}}-\mathrm{X}_{\mathrm{N}}+\mathrm{Y}_{\mathrm{N}} \geq 3, \mathrm{Y}_{\mathrm{W}}-\mathrm{Y}_{\mathrm{O}}+\mathrm{X}_{\mathrm{O}} \geq 5, \mathrm{Y}_{\mathrm{X}^{-} \mathrm{U}}+\mathrm{X}_{\mathrm{U}} \geq 10$,

$Y_{\text {Finish }}-Y_{R}+X_{R} \geq 3, Y_{\text {Finish }}-Y_{T}+X_{T} \geq 10, Y_{\text {Finish }}{ }^{-}+X_{V} \geq 5$,

$Y_{\text {Finish }}-Y_{W}+X_{W} \geq 5, Y_{\text {Finish }}-Y_{X}+X_{X} \geq 5, Y_{\text {Finish }} \leq 9$ (11)

Non-negative constraint for decision variable

$\mathrm{X}_{\mathrm{A}}, \mathrm{X}_{\mathrm{B}}, \mathrm{X}_{\mathrm{C}}, \mathrm{X}_{\mathrm{D}}, \mathrm{X}_{\mathrm{E}}, \mathrm{X}_{\mathrm{F}}, \mathrm{X}_{\mathrm{G}}, \mathrm{X}_{\mathrm{H}}, \mathrm{X}_{\mathrm{I}}, \mathrm{X}_{\mathrm{J}}, \mathrm{X}_{\mathrm{K}}, \mathrm{X}_{\mathrm{L}}$, $\mathrm{X}_{\mathrm{M}}, \mathrm{X}_{\mathrm{N}}, \mathrm{X}_{\mathrm{O}}, \mathrm{X}_{\mathrm{P}}, \mathrm{X}_{\mathrm{Q}}, \mathrm{X}_{\mathrm{R}}, \mathrm{X}_{\mathrm{S}}, \mathrm{X}_{\mathrm{T}}, \mathrm{X}_{\mathrm{U}}, \mathrm{X}_{\mathrm{V}}, \mathrm{X}_{\mathrm{W}}$, $X_{X} \geq 0$

Non-negative constraint for start time variables $\mathrm{Y}_{\mathrm{A}}, \mathrm{Y}_{\mathrm{B}}, \mathrm{Y}_{\mathrm{C}}, \mathrm{Y}_{\mathrm{D}}, \mathrm{Y}_{\mathrm{E}}, \mathrm{Y}_{\mathrm{F}}, \mathrm{Y}_{\mathrm{G}}, \mathrm{Y}_{\mathrm{H}}, \mathrm{Y}_{\mathrm{I}}, \mathrm{Y}_{\mathrm{K}}, \mathrm{Y}_{\mathrm{L}}$, $Y_{M}, Y_{N}, Y_{O}, Y_{P}, Y_{Q}, Y_{R}, Y_{S}, Y_{T}, Y_{U}, Y_{V}, Y_{W}$, $\mathrm{Y}_{\mathrm{X}^{\varepsilon}} \mathrm{Y}_{\text {Finish }} \geq 0$

Here the target of the project completion time has been taken as 90days. By crashing of 4 days from the duration of the project the target would be achieved. By solving the above LPP model, the crash cost and a crash time for each activity has been estimated and minimizes the total crash cost of the project.

\section{CONCLUSION}

By using deterministic and probabilistic technique in construction project, the project duration and cost are optimized. Initially the project duration was 120 days. After applying these techniques the project duration has been reduced to 94days. Using linear programming model the project duration of 94 days has been crashed to 90 days. This paper concludes that CPM and PERT techniques are useful for the optimizing time schedule of any construction project. The complexity of this model increases when more activities are considered and their precedence relationship is complicated. While preparing the network diagram less number of dummy activities increase the computation time and also the probabilistic model is mostly preferable by all the construction based companies as the activity durations are mainly depend on the workers, the raw materials arrival and other circumstances.

\section{REFERENCES}

[1]. M.K.Dhirendra Rao, PERT/CPM-Its application to library and information system, Annals of Library information studies, 25(1-4), 31-37, 1978.

[2]. Wayne A.Haga et al, crashing PERT networks: A simulation approach. Proceedings of international conference of the Academy of Business and Adminstrative Science Conference Quebec City, July 12-14, 2001.

[3]. Amir Azaron et al, A multi-object resource allocation problem in PERT network, European Journal of Operational Research 172,838-854, 2006.

[4]. Mr. K KOTESHWARA RAO et al, Optimal selection of PERT for large complex and distributed projects, International Journal of Computer Science and Network Security, 8(6), 7-18, 2008.

[5]. S.M.Fahimifard et al: Application of project scheduling in agriculture, American-Eurasian Journal of Agricultural and Environmental Science,5(3),313-321, 2009.

[6]. Eugen Rotarescu: Applying PERT and critical path method in human resource training, Review of General Management, 14(2),187-201,2011.

[7]. Omar M.Elmabrouk, A linear programming technique for the optimization of the activities in maintenance projects, International Journal of Engineering and Technology, 11(1), 24-29, 2011.

[8]. Adebowale S.A et al: Network analysis and building construction: Implication for timing and costing of activities, Journal of Civil Engineering and Construction Technology, 2(5), 90-100, 2011.

[9]. AjiboyeSuleAdegoke et al, Measuring process effectiveness using CPM/PERT, International Journal of Business and Management, 6(6), 286-295, 2011.

[10]. Rashmi Agarwal et al, Critical path method in designing feasiblesolution, IJSRR, 2(1) Suppl, 190-202, 2013.

[11]. M.A.Gurau et al, An overview of critical path applied to project management with win QSB software, International Journal 
of Mathematical models and methods in Applied Sciences, 6(7), 829-836, 2012.

[12]. ParitoshTamraka, Analysis and improvement by the application of network analysis, The International Journal of Engineering and Sciences, 2(1), 154-159, 2013.

[13]. Paramveer Sing et al, How to strength workers management relationship network techniques-A case study, International Journal of Innovative Research and Development, 2(11), 147-152, 2013.

[14]. Peng Wang, Optimization algorithms of pert network diagram in software project management system, Applied Mechanics and Materials, 321-324, 2056-2059, 2013.

[15]. Aditi S.Baghele, Evaluate the effective resource management through PERT analysis, International Journal of Research in Engineering and Technology,3,(9),5-9 ,2014.

[16]. Shailla, Comparative study of management operation system techniques (MOST) and CPM in construction scheduling, International Journal of Engineering Trends and Technology, Volume 18(8), 371-379, 2014.

[17]. Siddharth Chatwal, Application of project scheduling in a bottling unit startup using PERT and CPM techniques, International Journal of Advanced Research in Engineering and Applied Sciences, 3(6), 1-9, 2014.

[18]. AnujaRaguru, Parag Mahatme, Effective techniques in cost optimization of construction project, International Journal of Informative and Futuristic Research, 3(5), 1646-1658, 2016.

\section{Appendix A}

n-last node

$P(j)=\{$ immediate predecessors of node $j\}$

$\mathrm{S}(\mathrm{i})=\{$ immediate successors of node $\mathrm{i}\}$

$t_{i j}$-duration time of the activity $(i, j)$

$\mathrm{ES}(\mathrm{j})$-earliest start of the activity $(k, j)$

EC(j)-earliest completion of the activity $(k, j)$

LS(i)-Latest start of the activity (i,k)

LC(i)-Latest completion of the activity $(\mathrm{i}, \mathrm{k})$

TF-Total float

IF-independent float

FF-free float

$\mathrm{T}_{\mathrm{p}}$-total project completion time

$\mathrm{t}_{0}$ - optimistic time

$\mathrm{t}_{\mathrm{m}}$-most likely time

$t_{p}$ - pessimistic time

$\mathrm{t}_{\mathrm{e}}$-expected time 